> Tips om medisinsk litteratur, andre bøker, filmer og elektroniske medier som bør anmeldes, sendes tidsskriftet@legeforeningen.no

\section{Utforskende og åpent om kreft for barn}

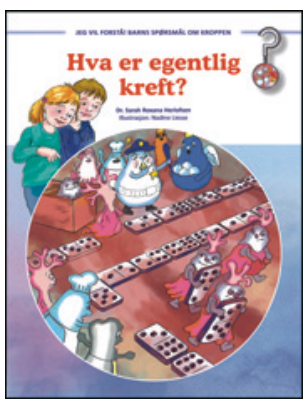

Sarah Roxana Herlofsen

Hva er egentlig kreft?

34 s, ill. Asker: Herosa, 2016.

Pris NOK 269

ISBN 978-82-690298-0-2

Med denne boken, gitt ut med støtte av Kreftforeningen, tar forfatteren for seg et utrolig viktig og krevende tema: Å snakke åpent med barn om kreft når et nært familiemedlem eller barnet selv rammes av sykdom.

Forfatteren har bakgrunn i molekylær biomedisin, noe som preger utgivelsen. I motsetning til lignende litteratur på området er det ikke en personlig historie som blir fortalt - dette er en faktabok med et biologisk og praktisk perspektiv. Denne distansen virker passende for å kunne belyse livets harde realiteter for tøffe små. I en forklarende og utforskende stil formidles innholdet $i$ et lett tilgjengelig språk, understøttet av Nadine Liesses fantasifulle illustrasjoner.

Oppbygningen er pedagogisk, i kapitler som kortfattet og forenklet gjennomgår normal cellebiologi, hvordan kreft oppstår, hvorfor dette kan resultere i alvorlig sykdom og de ulike behandlingsmulighetene vi har. Selv immunterapi har fătt sin egen lille del. Videre er det kapitler om å bli frisk, om når behandlingen ikke virker og om det aller tyngste - døden og hva som skjer med kroppen når vi dør. Det er konkret, men allikevel åpent.

En styrke ved utgivelsen er at man tar opp hverdagslige problemstillinger ved å leve med kreft, som «Kan jeg gi bestemor en klem selv om hun er syk?» og «Hvorfor er akkurat jeg blitt syk?»-en motvekt til at vektleggingen til tider kan bli vel biologisk.

Forfatteren har i høy grad lyktes med sitt mål - å bidra til å spre kunnskap, trøst og håp. Utgivelsen er et fint utgangspunkt for å bringe sykdom på banen i barnefamilien, særlig for litt større barn.

Elin Aamdal

Lege i spesialisering, Avdeling for kreftbehandling Oslo universitetssykehus

\section{Gode historier om tilfriskning}

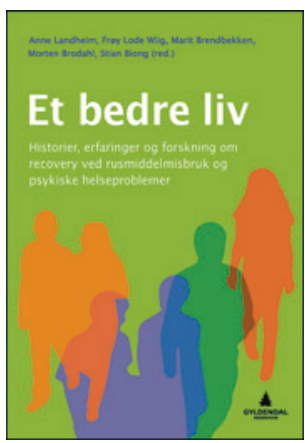

Anne Landheim, Frøy Lode Wiig,

Marit Brendbekken et al.

Et bedre liv

Historier, erfaringer og forskning om recovery ved rusmiddelmisbruk og psykiske helseproblemer. 210 s. Oslo: Gyldendal Akademisk, 2016. Pris NOK 349

ISBN 978-82-05-48032-2

Dette er en etterlengtet utgivelse. Det skrives for lite om hvordan pasientene selv opplever tilfriskningen innen psykisk helsevern og rus- og avhengighetsbehandling. Hva var det som skulle til for dem? Hvordan var deres vei? Denne boken gir innsikt formidlet av dem som er aller best rustet til å formidle den, nemlig dem som selv har slitt. Gjennom 14 pasienthistorier får vi personlige fortellinger om hvordan problemene kom, hva problemene var og veien ut av dem. Dette er førstehåndkunnskap å lære av. Det er interessant å oppdage hvordan ulike behandlingsfilosofier ofte blir en integrert del av mange pasienters historie - lærdommen blir en del av det nye liv som bygges. Men aller best og mest slående blir historiene når de formidler personlige innsikter også utenom dette, gjerne i et mer personlig og ikke-profesjonalisert språk. Mer enn én gang i lesingen ble jeg rørt.

Et bedre liv henvender seg bredt - til brukere, pårørende, studenter, fagfolk og politikere. Pasienthistoriene utgjør den midtre delen av boken. Men den er også utstyrt med to akademiske innledningskapitler og åtte mer drøftende kapitler i tredje og siste del. Disse til sammen ti kapitlene er skrevet av i alt 16 ulike forfattere og medforfattere. Dette mangfoldet er ikke til hinder for en helhetlig fremstilling uten unødvendige gjentagelser.

Kapitlene om selve begrepet «recovery» er interessante, om enn noe forvirrende. Uten at forvirringen er forfatternes feil, illustrerer dette hvor vanskelig og mangslungent, for ikke å si underlig, begrepet er. Det brukes om enkle ting som «tilfriskning» eller «bedring», men det tar også opp i seg pasientens egne ressurser og evner til tilheling. Det virker videre som om begrepet ofte brukes om mangt og meget av det som er vondt og galt i dagens behandlingsvesen - som diagnoser, industribindinger, objektforklaringer og maktstruktrer. Ole Petter Aksheim illustrerer dette godt i sitt kapittel, der begrepet og dets bruk gjennomgås i detalj. Det er på denne bakgrunn godt at mange av forfatterne velger å bruke «tilfriskning» og «bedring» i stedet for det diffuse «recovery».

Helge Waal formidler med utgangspunkt i pasienthistoriene at selv om avhengighet og psykiske plager er altomfattende lidelser av lang varighet, så er de ikke skjebnebestemte, livslange dommer man ikke kan komme ut av. Lars Lien formidler godt hvordan man kan bruke dette i det daglige arbeidet som behandler. Gode bidragsytere skriver om selvhjelp generelt og bruk av denne tenkningen i førstelinjetjenesten. Men mest fremtredende og viktigst i boken er de 14 personlige beretningene om hvordan det $\mathrm{i}$ beste fall kan gå. Det finnes håp.

Jørgen G. Bramness

Professor, Senter for rus og avhengighetsforskning Universitetet i Oslo 